Cahiers $d u$ MONDE RUSSE

\section{Cahiers du monde russe}

Russie - Empire russe - Union soviétique et États indépendants

$44 / 1 \mid 2003$

Varia

\title{
The alteration of place names and construction of national identity in Soviet Armenia
}

\section{Arseny SAPAROV}

\section{OpenEdition}

\section{Journals}

Édition électronique

URL : https://journals.openedition.org/monderusse/8604

DOI : 10.4000/monderusse.8604

ISSN : $1777-5388$

Éditeur

Éditions de l'EHESS

\section{Édition imprimée}

Date de publication : 1 janvier 2003

Pagination : 179-198

ISBN : 2-7132-1812-8

ISSN : $1252-6576$

Référence électronique

Arseny SAPAROV, "The alteration of place names and construction of national identity in Soviet Armenia », Cahiers du monde russe [En ligne], 44/1 | 2003, mis en ligne le 01 janvier 2007, consulté le 02 septembre 2022. URL : http://journals.openedition.org/monderusse/8604 ; DOI : https://doi.org/ 10.4000/monderusse. 8604 
chercher : repérer : avancer

Cet article est disponible en ligne à l'adresse :

http://www.cairn.info/article.php?ID REVUE=CMR\&ID NUMPUBLIE=CMR 441\&ID ARTICLE=CMR 4410179

The alteration of place names and construction of national identity in Soviet Armenia

par Arseny SAPAROV

| Editions de l'EHESS | Cahiers du monde russe

$2003 / 1$ - Vol 44

ISSN 1252-6576 | ISBN 2713218128 | pages 179 à 198

Pour citer cet article :

- SAPAROV A., The alteration of place names and construction of national identity in Soviet Armenia, Cahiers du monde russe 2003/1, Vol 44, p. 179-198.

Distribution électronique Cairn pour les Editions de l'EHESS.

(C) Editions de l'EHESS. Tous droits réservés pour tous pays.

La reproduction ou représentation de cet article, notamment par photocopie, n'est autorisée que dans les limites des conditions générales d'utilisation du site ou, le cas échéant, des conditions générales de la licence souscrite par votre établissement. Toute autre reproduction ou représentation, en tout ou partie, sous quelque forme et de quelque manière que ce soit, est interdite sauf accord préalable et écrit de l'éditeur, en dehors des cas prévus par la législation en vigueur en France. Il est précisé que son stockage dans une base de données est également interdit. 


\section{THE ALTERATION OF PLACE NAMES AND CONSTRUCTION OF NATIONAL IDENTITY IN SOVIET ARMENIA*}

Place-names are some of the most durable of national symbols. They can outlive most material artefacts of a civilisation. The material components of the cultural landscape may disappear or be destroyed, the civilisation that created them may also disappear but its place-names will most probably survive. In this capacity place-names are important features of national and territorial identity. According to D. W. Meinig, "Every mature nation has its symbolic landscapes. They are part of the iconography of nationhood, part of the shared set of ideas and memories and feelings which bind a people together." Ethnic groups that have preserved their national identity are especially sensitive about the maintenance of the national landscape. Often the national toponymy is the only witness to the fact that a territory belongs to a particular ethnic group. Most definitions of any ethnic community - tribe, nationality, nation necessarily mention the common living space of that ethnic group. Within that territory a national toponymy has been formed - a system of geographic names in the native language of the indigenous population. "The existence of these names clearly defines the territory of that ethnic group and is one of the most important expressions of the national identity. The use of national toponymy ensures historical continuity, preservation of cultural traditions of a nation. [...] The native toponymy acquires special meaning for small stateless nations as it alone identifies their national territory." 2 It is therefore not

* This research would be impossible without the generous support of the Tweedy Exploration Fellowship (University of Edinburgh) and an RSS grant (Research Support Scheme, Prague, OSI). I am also grateful to Professor Nina Garsoïan and Dr. Alex Clayton-Jolly for correcting the final version of the text.

1. D. W. Meinig, "Symbolic landscapes," in id., ed., The interpretation of ordinary landscapes (New York: Oxford University Press, 1979): 164.

2. E. M. Pospelov, "Natsional'naia politika SSSR i toponimiia," in Toponimika i mezhnatsional'nye otnosheniia (Moscow: AN SSSR, Moskovskii filial Geograficheskogo obshchestva SSSR, 1992): 3. 
surprising that place-names and ideology are related. The conscious use of placenames by a state can be seen as an instrument to preserve the unity and uniqueness of the nation; to enforce in the national consciousness its moral right to inhabit a particular territory; to protect its land from the territorial claims of its neighbours; or to justify its own territorial claims. A recreated or artificially created place-name landscape is a symbolic part of national identity. Therefore, toponymy is an important part of a state's or nation's ideological system.

From the point of view of traditional onomastics all place-names undergo continual development within a language changing phonetically and semantically. The former type of change consists of primarily sound shifts in a language, and the latter changes occur from cultural transformation when some words are lost from common usage. Both changes eventually lead to the obscuration and substitution of the original meaning. ${ }^{3}$ The situation of languages in contact is much more complex as both languages exercise a mutual influence on the place-names, leading to a more complicated pattern of place-name changing which includes phonetic transfer from one language to the other, translation, folk-etimological transfer, and visual transfer. This often results in conflicting situations arising from different cultural and ethnic emotional attitudes. ${ }^{4}$ We have thus established that place-name alteration, be it within one language or between several languages is not an unusual phenomenon. The goal of this paper however, is not to trace the linguistic transformations and origins of the place-names in the Armenian SSR, but to understand the ideological and political motivation behind the place-name changes. This means that the classifications of place-names employed here reflect purely political perceptions rather than true origins of a place-name. To illustrate this point: a number of Turkic place-names are adaptations of the earlier Armenian place-names, however, from the nationalist Armenian perspective they remained Turkic.

\section{Place-naming policy in the USSR}

It is common for revolutionary regimes to create new state symbols to "remove evidence of the deposed regime and to establish an identity for the usurper." 5 This is exactly what the Soviet Union did by destroying the churches, monuments, institutions and place-names of the Tsarist regime. ${ }^{6}$ The Bolsheviks undertook

3. George R. Stewart, Names on the globe (New York: Oxford University Press, 1975): Part I, chapters 6 and 8

4. Ivan Lutterer, "Czech-German language contacts in the toponymy of Bohemia;" J. B. Rudnyckyj, "Names in contact: Canadian pattern;" G. F. Delaney, "Language problems in Canadian toponymy;" in Henri Dorion, ed., Les noms de lieux et le contact des langues = Place names and language contact (Québec: Les Presses de l'Université Laval, 1972).

5. Peter G. Lewis, "The politics of Iranian place-names,” The Geographical Review, 72 (1982): 99.

6. I would like to stress the important difference between the material symbols that affect primarily a visual perception and place-names that aim at embedding ideological and aesthetic values into the consciousness. 
unprecedented place-name changing campaigns managing to replace up to half of all place-names in the USSR. ${ }^{7}$ To sum up, it is possible to say that any place-name changes in the USSR were directly related to the ideological, political and national policy of the authorities. ${ }^{8}$ The place-names policy was regulated at the highest Soviet level by the decrees of the Central Executive Committee, and the Supreme Soviet.

\section{Place-names, demography and national identity}

The South Caucasus was an arena of constant warfare between the Ottoman and Persian empires for some three hundred years from the fifteenth century. The character of those wars had a devastating effect on the region. Both sides implemented a scorched earth policy to deprive their adversary of resources and to impede their advance. To this end large-scale deportations of the indigenous population were carried out, particularly by the Persians who were predominantly on the defensive and needed to stop the advancing Ottoman troops. ${ }^{9}$ Hundreds of thousands of people were displaced in this manner; their villages remained deserted and after some time were inhabited by nomadic Turkic tribes. This situation of constant warfare had a profound impact on the place-names in the region and especially in Armenia. This situation closely matches the circumstances described by G. R. Stewart: "If the transfer of the territory occurred in haste and under stress,

7. Charles B. Peterson, "The nature of Soviet place-names," Names, 25, 1 (1977): 15-24; N. V. Podol'skaia, "Sviazi demografo-etnicheskikh i toponimicheskikh protsessov," in Toponimika i mezhnatsional'nye otnosheniia (Moscow: AN SSSR, Moskovskii filial Geograficheskogo obshchestva SSSR, 1992): 24; John Murray, Politics and place-names. Changing names in the late Soviet period (Birmingham: Birmingham Slavonic Monographs No. 32, University of Birmingham, 2000): 1.

8. Along with the establishment of ideologically motivated place-names there were place-name campaigns that can be seen as Russian nationalistic. For instance, Finnish place-names were replaced by the Russian ones on the territories annexed from Finland with the exception of Karelo-Finnish ASSR. (Charles B. Peterson, art. cit.: 23). Even before the Second World War the mass deportations of people accused of collaborating with the Nazis - Crimean Tatars, Volga Germans, Kalmiks, Balkars, Karachay - were followed by mass renaming campaigns, when Russian and Soviet place-names were imposed. The same tendency was revealed after the war in Eastern Prussia (present-day Kaliningrad oblast' of Russian Federation), when all German place-names were replaced in July 1946 by Russian and Soviet place-names. A similar fate befell the Japanese place-names in the Southern Sakhalin and Kuril Islands after the Second World War. The deterioration of Russian-Chinese relations in December 1972 resulted in the replacement of Chinese place-names in the border districts (Charles B. Peterson, art. cit.: 15-24). Up to 500 place-names were changed in the Far East. (B.A. Diachenko, "Pereimenovaniia v primor'e," in Vsesoiuznaia nauchno-prakticheskaia konferentsiia "Istoricheskie nazvaniia - pamiatniki kul'tury" 17-20 aprelia 1989. Tezisy dokladov i soobshchenii (Moscow, 1989): 111. Russification policies were continued in the late Soviet period in Ukraine and Moldova. (S. G. Berzhan, "O tendentsiiakh iskoreneniia istoricheskikh nazvanii (Na materiale natsional'nykh toponimov MSSR)," in ibid.: 112).

9. See: Dickran Kouymjian, "Armenia from the fall of the Cilician Kingdom (1375) to the forced emigration under Shah Abbas (1604)," in Richard G. Hovannisian, ed., The Armenian people from Ancient to Modern Times, vol. 2 (London: Macmillan, 1997): especially 14-21. 
during a warlike invasion, when some horde may have descended upon a district and slaughtered the inhabitants so quickly and so totally that killers learned no names we shall expect less care in rendering than if it took place during friendly and leisurely contacts of trading." 10 Under these conditions, the total replacement of the cultural landscape becomes possible. In the case of Eastern Armenia, deportations took the place of a massacre so that new arrivals would not be able to learn the original place-names. This argument is reinforced by the Russian nieneteenthcentury explorer of the South Caucasus Ivan Shopen who wrote that: "Geok-Chai magal [district] after the devastation of the previous century remained entirely empty so when the last Yerevan sardar Hussein-Khan undertook to resettle it with Karapapakhs in 1814 no one could remember the names of its destroyed villages, that have since received new names." 11 Other indirect evidence pointing at forced migrations is that a number of Turkic place-names in Armenia have the ArabicTurkic root harab/haraba, meaning ruins. Over the centuries, the highly unstable political situation in the region, the large-scale displacements of the Armenian population and the penetration of Turkic nomadic tribes resulted in a dramatic transformation of the ethnic composition of the region and its cultural landscape. The Armenian toponymic nomenclature partially survived, but is largely adapted, altered, or entirely replaced by the Turkic one.

\section{The Russian Empire in the South Caucasus}

The acquisition of the South Caucasus by the Russian Empire during the first three decades of the nineteenth century led to dramatic demographic changes in the region. The military and strategic designs of the Russian authorities required the establishment of a buffer zone inhabited by a friendly Christian population between the Russian territory and the Islamic Empires of Persia and Turkey. The colonisation of the South Caucasus by ethnic Russians proved impossible due to the high costs as well as the inhospitable environment. Therefore, the Russian authorities greatly encouraged the resettlement of Christian Armenians. Within a short period from 1828 to 1831 , it is estimated that 105,000 Armenians arrived in the South Caucasus. ${ }^{12}$ Their main destination was the newly created "Armianskaia oblast"" (the Armenian Province) made up of the Yerevan and Nakhijevan Khanates. The results of this policy can be seen from the fact that the population of the Armianskaia oblast' in 1831 was $49.7 \%$ Muslim, and $34.8 \%$ resettled Armenians while only $15.3 \%$ were indigenous Armenians. ${ }^{13}$ This process

10. G. R. Stewart, op. cit.: 53.

11. Ivan Shopen, Istoricheskii pamiatnik sostoianiia Armianskoi oblasti v epokhu ee prisoedineniia $k$ Rossiiskoi imperii (St. Petersburg, 1852): 446. In addition the author lists 1,111 villages of the Armianskaia oblast' and 359 of those were destroyed villages, ibid.: 485-508, 510-518.

12. M. A. Adonts, Ekonomicheskoe razvitie Vostochnoi Armenii v 19 veke (Yerevan: Academy of Science of the Armenian SSR, 1957): 496, 499.

13. Ivan Shopen, op. cit.: 639-642. 
continued through the entire nineteenth century fuelled by the Russian-Turkish (Crimean) war of 1855-1856, the Russian-Turkish war of 1877-1878, by the Armenian massacres in the Ottoman Empire in the late nineteenth century and especially during the First World War as a result of genocidal policies carried out in the Ottoman Empire. ${ }^{14}$ By the time of the declaration of independence in 1918 at the end of the World War I, there were some 400-500 thousand refugees in Eastern Armenia. ${ }^{15}$ Thus in less than a century (1828-1918) the demographic structure of Eastern Armenia changed in a most dramatic way - from a tiny minority at the beginning of the nineteenth century Armenians became a sizeable majority by the early twentieth century. These demographic developments had implications, which are clearly seen in the early Soviet population census (1926). ${ }^{16}$

The population of Armenian SSR in 1926

\begin{tabular}{lcccc}
\hline \multicolumn{1}{c}{ District } & Armenians & \% & Azerbaijanis & \% \\
\hline Daralagiaz & 23,959 & 79.6 & 5,941 & 19.7 \\
Delijan & 66,934 & 85.0 & 8,181 & 10.3 \\
Zangezur & 59,938 & 86.9 & 4,433 & 6.4 \\
Leninakan & 146,257 & 87.6 & 1,505 & 0.9 \\
Megri & 6,517 & 80.0 & 1,201 & 14.7 \\
Nor-Bayazet & 85,790 & 84.4 & 14,065 & 13.8 \\
Pambak-Lori & 106,911 & 80.2 & 10,616 & 7.9 \\
Erivan & 146,347 & 81.9 & 24,039 & 13.4 \\
Echmiadzin & 100,918 & 88.1 & 8,247 & 7.2 \\
\hline Total & $\mathbf{7 4 3 , 5 7 1}$ & $\mathbf{8 4 . 4}$ & $\mathbf{7 8 , 2 2 8}$ & $\mathbf{8 . 8}$ \\
\hline
\end{tabular}

This table shows that by 1926 the Armenian population formed an $84.4 \%$ majority in the republic overall $(8.8 \%$ Turkic); $89.2 \%(149,183)$ majority in urban areas

14. Armenian refugees fled into Eastern Armenia even before the large-scale massacres began in the Ottoman Empire in spring 1915. Thus according to the data collected during the one-day census by the Erevan Statistical Committee on January 30, 1915, on the territory of Eastern Armenia there were more than 67,000 refugees - Armenians, Greeks, Assyrians. Armenians made up some 50,000 of this total. See: Erevanskaia statisticheskaia komissiia. Odnodnevnaia perepis' bezhentsev iz Turtsii, Persii i iz mest pogranichnykh s Turtsiei (armian, aisorov, grekov i dr.) 1914-1915. Perepis' proizvedena 30-go Ianvaria 1915 goda (Yerevan: "Luis," 1915): 38-39.

15. Richard G. Hovannisian, The Republic of Armenia, vol. 1: The first year, 1918-1919 (Berkeley - Los Angeles: University of California Press, 1971): 48.

16. Zakavkazskoe Statisticheskoe Upravlenie. Naselenie Zakavkaz'ia. Vsesoiuznaia perepis' naseleniia 1926 g. Kratkie itogi (Tiflis, 1928): table 6, p. 13. 
$(3.4 \%(5,703)$ Turkic), and $84.8 \%(605,393)$ in rural areas $(10.1 \%(72,525)$ Turkic).

\section{National movement in Armenia}

The "Armenian Question" was brought into the international agenda at the Berlin Convention of 1878, which obliged the Ottoman Government to carry out reforms in the Armenian provinces ${ }^{17}$ Meanwhile, Armenian national ideology was under the strong influence of the national-liberation movement in the Balkans as well as of the ideas of the Russian socialists, the "Narodniki" in particular. ${ }^{18}$ The Armenian political parties that emerged in the late nineteenth century were mainly concerned with the liberation of Western (Turkish) Armenia. Their ideas were further fuelled by the demands for autonomy and reform for Armenia that were being made in the European and Russian diplomatic notes of the time. This rising Armenian nationalism was necessarily in sharp conflict with the emerging Turkish nationalist ideology. The Ottoman State under Sultan Abdul-Hamid II responded by carrying out the Armenian massacres of the late nineteenth century. This policy eventually culminated in the Armenian genocide of 1915, when almost the entire Armenian population was erased from Western (Turkish) Armenia, which put an end to all hopes of an independent Armenian state in Western Armenia. Given the importance of the notion of an independent Armenia, it is clear that the events of 1915 had the most profound and traumatic effect on the Armenian national identity.

\section{Place-naming policy in Soviet Armenia}

Having outlined the aspects of the Armenian national identity, demographic circumstances and origins of place-names in the Armenian SSR we can now turn to the ideological use of renamings in Soviet Armenia. This part will address four aspects of the renamings - the mechanism of renamings will unveil the Soviet bureaucratic procedures that led to the place-name renaming. The dynamics of renamings will address the relationship between the ideological and political developments in the USSR and renamings in Armenia. The scale of renamings will deal with the fluctuating numbers of place-names in Armenia and the spatial distribution of the renamings. Finally, the nature of renamings will be analysed in the last part.

17. J. C. Hurewitz, The Middle East and North Africa in world politics. A documentary record, 2nd ed., revised and enlarged, vol. 1: European expansion, 1535-1914, compiled, translated, and edited by J. C. Hurewitz (New Haven - London: Yale University Press, 1975): 414.

18. M. R. Kochar, Armiano-Turetskie obshchestvenno-politicheskie otnosheniia i armianskii vopros $v$ kontse 19 - nachale 20 vekov (Yerevan: Izdatel'stvo Erevanskogo Universiteta, 1988): 17-19. 


\section{Mechanism of renamings}

The Soviet system of totalitarian control embraced all aspects of public life. Every minor decision had to be in accordance with the supervising authority. This was true for place-naming as well. During the Soviet period a special framework of laws and instructions was created to regulate a renaming policy. This mechanism was neither public nor uniform for all the Soviet republics. From a number of documents I will try to reconstruct the mechanism of renamings used in Armenia. Some of the decision-making aspects in Armenia can be seen from a 1927 law that reads:

1. The names of newly established places had to be approved by the Presidium of the Central Executive Committee [of the Armenian SSR]; a request for it had to be submitted by the district executive committee through the People's Commissariat of Internal Affairs. 2. The names of the new railway stations opening within the boundaries of the Armenian SSR, had to be approved by the Central Executive Committee of the Armenian SSR, with the [subsequent] approval by the People's Commissariat of Communications of the USSR. ${ }^{19}$

As we can see, the place-naming policy even at a local level was closely controlled by the Central authorities from the outset. Another element in the mechanism of renamings was a special commission which was appointed in 1933 to determine "correct" place-names in Armenia. ${ }^{20}$ A number of sources allow us to reconstruct the process by which the "correct" place-names were approved at the different levels of authority. The first stage in this mechanism was the Geographic Commission of the Armenian Academy of Science that would accept the new place-names. The next stage was at the Presidium of the Academy of Science where the suggested place-names were reviewed. A further decision had to be made by the Presidium of the Supreme Soviet of the Armenian SSR. ${ }^{21}$ The final decision on renaming had to be "co-ordinated in every case [...] with the Presidium of the Supreme Soviet of the USSR. [...] According to the decision taken on April 15, 1938 by the Supreme Soviet of the USSR." 22 Hence, there existed a four level

19. "Nor Kazmvoh Bnakavajreri Tomaragrman ev Anvanman Kargi Masin: 19. 01. 1927," Haikakan SSR Orenkneri, Geraguin Soveti Nakhagahutian Hramanagreri ev Haikakan SSR Karavarutian Voroshumneri Zhamanakagrakan Zhohovatzu 1920-1938 tt. (Ar 1-i hulisi 1963 t. popohutiunnerov ev lratzumnerov) (Chronological collection of the laws of the Armenian SSR, the decrees of the Presidium of the Supreme Soviet and decisions of the government of the Armenian SSR, 1920-1938) (Yerevan: Haipetrat, 1963): 241.

20. Mary Kilbourne Matossian, The impact of Soviet policies in Armenia (Leiden: E. J. Brill, 1962): 80,142 .

21. Haikakan SSR Ashkharagrakan Anunner (The Geographic Names of the Armenian SSR) (Yerevan: Academy of Science of the Armenian SSR, 1951): 6, 9-10.

22. "Haikakan KhSH Varchakan-Teritorial Bazhanman Hartseri Lutsman Kargi masin. 14. 05. 1938," Haikakan SSR Orenkneri..., op. cit.: 361 . 
system of adopting decisions on place-name renamings, allowing Moscow control of the entire place-naming process:

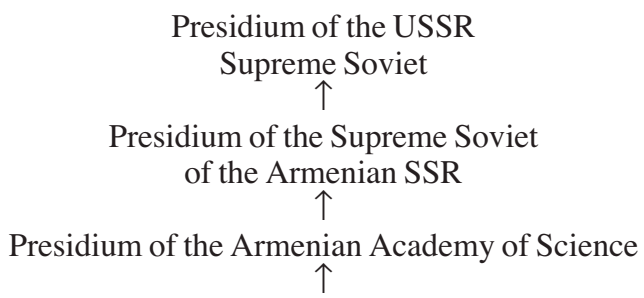

The Geographic Commission of the Armenian Academy of Science

I should point out that this mechanism was reconstructed through the analysis of a number of documents that cover the period from 1930 to the mid 1950's. So far, I have not discovered a single document that contains a direct reference to all the components of the process. Nevertheless, it is clear that the politics of renamings was under tight political control.

\section{The dynamics of renamings}

The place-name renamings in the Armenian SSR became an indicator closely reflecting the internal political processes in the USSR. In the early years of communist rule, ideas of internationalism were particularly strong among Armenia's communist leaders. This is clearly reflected in the renamings of that time. There is no exact data on renaming policies for the period 1920-1934, but the number of renamings at that time can be estimated at no more than 80 from an analysis of indirect sources..$^{23} \mathrm{~A}$ characteristic of the early renamings is that the toponyms renamed were mainly of a religious nature, especially unacceptable for the Soviet authorities during the first decades of Soviet rule. Both Christian and Muslim place-names were targeted. For instance, such Christian and Muslim placenames as: Mollalu (Aluchalu Verin), Kilisakend (Srashen), Hojakend (Kuzikend), Kodukhvank (Koturvan), ${ }^{24}$ etc. lost their religious element. Another category, consisting of place-names reflecting feudal relationships, was equally unacceptable: Hussein Kuli Agalu (Narimanlu), Siltan Ali Kishlag (Janahmed), etc.

23. This estimation is based on the following calculations: the very first edition of the administrative-territorial division of the Armenian SSR (1948) listed around 80 renamed placenames without the date of renaming. Having in mind that place-names renamings with the date of renaming began in 1935 it is possible to assume that 80 dateless renamings have occurred in the period of 1920-1934.

24. Place-name in brackets is a new one. The religious connotation here is as follows: Mollalu means Mullah; Kilisakend is Turkish for Church; Hojakend relates to a pilgrimage to Mecca; - vank in Kodukhvank is Armenian for Church. 
The reason for these renamings is clearly stated in an official decree on renamings of 1935:

Resolution of the Presidium of the Central Executive Committee of the SSRA

Taking into consideration that names of many populated places of the SSRA reflect relict religious, feudal-landowner relations and are alien to the Soviet consciousness, and [moreover] some have unstable and even derogative meaning, as well as that many place-names are repeated in two or more areas which creates postal and other inconveniences, the Presidium of TsIK [Central Executive Committee] SSRA complies with the opinion of workers and local organisations and has decided: 1. to change names of populated places, according to the following list: [list of place-names]

Secretary of TsIK SSRA - R. Dashtoian

January $3,1935^{25}$

During the period 1941-1945 of the Great Patriotic War, there were no renamings in the Armenian SSR. The only exception was one renaming of a Russian village Voskresenovka into Lermontovo, to commemorate the 100th anniversary of the Russian poet Lermontov's death in 1941. This particular renaming also allowed the authorities to get rid of an undesirable religious toponym (Voskresenovka means Resurrection). The place-name renamings of 1945 occurred after the capitulation of Nazi Germany. The significant increase in the number of renamings between 1946 and 1950 was a product of both social and political processes. One of these was the mass repatriation of Armenians in the aftermath of the war. The Soviet government adopted a decision to repatriate Armenians into Soviet Armenia in November 1945. ${ }^{26}$ The returning Armenians became Soviet citizens the moment they arrived in the USSR. ${ }^{27}$ In the period 1946-1948 some 90,000 Armenians arrived from the Middle East, North and South America and Western Europe. ${ }^{28}$ Another socialpolitical process that apparently affected place naming in Armenia was the emigration of Azerbaijanis from the Armenian SSR that occurred in that period. On March 10, 1948, the Council of Ministers of the USSR adopted a resolution

25. Kommunist(Yerevan), 5 (05.01.1935). The comparison of the list of renamings published in the Kommunist newspaper (104 renamings) with the list of renamings that appeared in the 1948 edition of the Administrative-territorial division of the Armenian SSR (97 renamings) shows that several place-names had disappeared from the map of Armenia between 1935 and 1948.

26. According to the decree of Sovnarkom of the USSR of November 21, 1945 the Armenian government received significant assets for the organisation of repatriation and for offering help to the repartees. The plenum of the Armenian Communist Party held in February 1946 had discussed "Measures on preparation for admittance and settlement of Armenians returning from abroad." Ocherki istorii kommunisticheskoi partii Armenii (Yerevan: "Ayastan," 1967): 445 .

27. Sbornik zakonov SSSR i ukazov Presidiuma Verkhovnogo Soveta SSSR 1938-1961 (Moscow, 1961). "O poriadke priobreteniia grazhdanstva SSSR litsami armianskoi natsional'nosti, vozvrashchaiushchimisia iz-za granitsi na rodinu v Sovetskuiu Armeniiu," Decree of October 19, 1946, p. 99.

28. Barbara A. Anderson and Brian D. Silver, "Population redistribution and the ethnic balance in Transcaucasia," in Ronald G. Suny, ed., Transcaucasia, nationalism, and social change; essays in the history of Armenia, Azerbaijan, and Georgia (Ann Arbor: University of Michigan Press, 1996): 488. 
entitled: "Planned measures for the resettlement of collective farm workers and other Azerbaijanis from the Armenian SSR to the Kura-Arax lowlands." According to this plan some 100,000 people had to be "voluntarily" resettled. The emigration occurred in three stages: 10,000 people were resettled in 1948, another 40,000 in 1949, and 50,000 in 1950. ${ }^{29}$ The Azerbaijani authors M. M. Allahverdiev and A. K. Aleskerov provide the following explanation of the resettlement of Azerbaijanis:

The influx of the population from beyond the republic in the post-war years is also caused by considerable extension of irrigated lands in the Kura-Araks lowland and by transmigrating to the republics the Azerbaijanis from Transcaucasian, Central Asian republics and some other regions that was organized in connection with it (during the years from 1948 to 1952 from the Armenian republic alone approximately 58,000 people were transmigrated to Azerbaijan) ${ }^{30}$.

These waves of emigrations of the Azerbaijani population and immigrations of Armenians were apparently one of the major causes for renamings in the Armenian SSR in the post-war period. We should also consider the general decline in RussoTurkish relations in the aftermath of the Second World War, and Stalin's demands for the return of the territories seceded to Turkey in $1921 .^{31}$ The post-war renamings campaign ended in 1950, and the annual number of renamings steadily declined until 1967-1968.

The years 1967 and 1968 were marked by a sudden increase in renamings when more than 50 place-names were changed. The explanation for this phenomenon could be the attempt of the local authorities to accommodate the resurgence of Armenian nationalism that occurred two years earlier. Let us assess the events of 1965 and their possible impact on the rise of renamings two years later. The unauthorized demonstrations took place in Yerevan in April 1965 to commemorate the 50th anniversary of the Armenian genocide in the Ottoman Empire. The event was not a totally unexpected one as there are indicators that it was anticipated. The local Kommunist newspaper published an article about one of the leaders of the Armenian liberation movement Andranik Ozanian whose very name was previously banned in the USSR several weeks before April 24. Immediately before the demonstrations the top official Soviet newspaper Pravda published an article about the Armenian genocide on April 24th - the day that is commemorated as

29. U. Barsegov, "Lozh' na sluzhbe ekspansionizma i genotsida," Armianskii Vestnik, 3-4 (1998): 138; Idayat Orudzhev (the state councillor of Azerbaijan on ethnic policy) during the 1994 conference also mentions a figure of 100,000 re-settled people and the following dates of decrees: December 23, 1947, and as already mentioned March 10, 1948. Open Society Archives. Soviet "Red" Archives / Fond 300 / Subfond 80 / Series 3 / Box 10 / Folder: "Armenia."

30. M. M. Allakhverdiyev, A. K. Aleskerov, "Regularities of changes in the territorial distribution and occupational cross-sections of the population in the Azerbaijan SSR," in Materials on economic history of Azerbaijan (To the Vth International Congress on Economic History) (Baku: Elm, 1970): 131.

31. Bruce Robellet Kuniholm, The origins of the cold war in the Near East; great power conflict and diplomacy in Iran, Turkey, and Greece (Princeton, NJ: Princeton University Press, 1980): 255-275. 
genocide day. The article was reprinted by the Armenian Kommunist the next day. ${ }^{32}$ The most unusual aspect of this event was that the Soviet authorities did not resort to violence as they had previously on similar occasions. ${ }^{33}$ Even though the absence of violence could have been interpreted as Soviet tolerance of the Armenian national (anti-Turkish) sentiment, it was however clear that the unauthorized nature of the demonstrations could not pass unnoticed. These events eventually lead to the resignation of the First Secretary of the Central Committee of the Communist Party of Armenia, V. Zorobian in 1966. One of the official reasons for his resignation was: "shortcomings in the ideological work of the party organisations [and] especially with the youth." ${ }^{4}$ Once the issue was resolved with Zorobian's removal the new Armenian communist leadership could make further concessions to Armenian nationalism to gain popular support. Indeed, the years 1967 and 1968 were marked by a set of symbolic gestures to nationalist sentiments.

One of the most notable consequences of the 1965 demonstrations was the construction and opening of the memorial to the victims of the genocide in Yerevan in 1967. This was clearly a concession to the national and especially anti-Turkish sentiments present in Armenian society. The new First Secretary of the Armenian Communist Party A. Kochinian attended the opening ceremony, which shows that the communist authorities took the mood of Armenian society seriously. In order to highlight the role of the Communist Party and to downplay the nationalist component of the event, the opening ceremony took place on November 29th the day of the sovietisation of Armenia, instead of April 24th as one might have expected. ${ }^{35}$ This 'Solomon' decision demonstrates that the local authorities needed to balance carefully the two tendencies - communism and nationalism, while trying to expertly combine them.

Yet another monument was opened in Armenia in 1968. This memorial was to celebrate the 50th anniversary of the Sardarapat battle of 1918. The battle between Armenian troops and the advancing Turkish army saved Armenia's capital by diverting the Turkish advance. The first secretary A. Kochinian again attended the ceremony to highlight the importance and significance of the event. Again, the date was carefully selected - May 26th - the day the Sardarapat battle began, rather than May 28th - the day of victory and of the declaration of Armenian independence. ${ }^{36}$ Along with these visible symbolic concessions to Armenian nationalism, a renaming campaign took place in 1967 and 1968. It is in this context that one should view the renamings of 1967-1968, as they were hardly accidental.

32. M. Nersisian, "Genotsid - tiagochaishee prestuplenie protiv peredovogo chelovechestva," Pravda (24.04.1965); Kommunist (Yerevan) (25.04.1965).

33. For instance in 1956 in Tbilisi, or in 1962 in Novocherkassk. For a detailed summary of those events see: V. A. Kozlov, Massovye besporiadki v SSSR pri Khrushcheve i Brezhneve (Novosibirsk: Sibirskii khronograf, 1999), chapters 5 and 12.

34. "K 23 s" ezdu KPSS, 16 marta 1966 goda," Open Society Archives. Soviet "Red" Archives/Fond 300/Subfond 80/Series 1/Box 47/Folder: "Armenia KP2."

35. Kommunist(Yerevan), (30.11.1967).

36. Kommunist (Yerevan), (26.05.1968). 
Following the unauthorized demonstrations of 1965, the Zorobian leadership was more reluctant to make any concessions to nationalist sentiment, as from Moscow's point of view, that would undoubtedly look provocative and could lead to accusations of nationalism. It is clear therefore why during the years 1965-1966, there were no renamings or any other expressions of nationalism. Moscow's stance became clear with Zorobian's "punishment" for the lapses in discipline, and notably, the absence of explicit condemnation of Armenian (anti-Turkish) nationalism. The new Armenian leadership was free to make concessions to nationalist sentiments and as a result the years 1967 and 1968 were marked by such symbolic gestures as the construction of monuments and renamings. Following the rise of Armenian nationalism and the renaming campaign of 1967 and 1968, there were virtually no renamings for another decade.

It was only in 1978 that another significant increase in renamings occurred when 91 place-names were changed. Once again, the explanation for this increase in renamings may be Armenian nationalism. It appears that Moscow's attempt to limit the constitutional rights of the Union republics (in particular, with regard to the very sensitive language issue) produced a nationalistic response in the form of the renaming campaign. A major propaganda campaign was conducted in the central Soviet press in the wake of the replacement of the old, so-called "Stalin's Constitution" (of 1936) in 1977 and 1978. It was clear that the aim of the campaign was to prepare the general public to expect further limitations in the rights of the Union republics. Even the federate nature of the USSR was questioned in favour of a unitary state. The Kremlin's desire for higher centralisation of the state was evidently shown in the project of the USSR Constitution, published in 1977. For instance, even the formal right to have military formations in the Union republics was removed. It was also proposed that Russian should become the state language.${ }^{37}$ In addition to the imminent changes in the USSR Constitution, the individual constitutions of the Union republics were also expected to change. With the unmistakable trend to the centralisation in the USSR constitution, it was natural to expect further limitations of rights at this time in the republican constitutions. When the drafts of the Armenian, Azerbaijani, and Georgian constitutions were published in 1978, there was no mention in the local press of the state languages of the republics. The authorities apparently expected discontent over the absence of the state language article in the constitution and as a concession to the national feelings the drafts of the Armenian and Georgian Constitutions mentioned "state concern for the development of the language." This encroachment attempt generated resentment and protests took place in Tbilisi and Yerevan in April 1978. ${ }^{38}$ As a result, the Soviet authorities opted for

37. Ann Shelly, "The non-Russian republics in 1977," Radio Liberty Research, RL 294/77 (December 27, 1977). Open Society Archives. Soviet "Red" Archives/Fond 300/Subfond 610/ Series 0/Box 1515/Research Bulletin 1977 (Oct.-Dec.).

38. "Demonstrations reported in capital of Soviet Georgia," Radio Liberty Research, RL 8 /78 (April 16, 1978); and "The Georgian language and national pride prevail," Radio Liberty Research, RL 81 / 78 (April 18, 1978). Open Society Archives. Soviet "Red" Archives/Fond 300/Subfond 610/Series 0/Box 1517/Research Bulletin 1978 (April - June). 
preserving the language articles not only in the Armenian and Georgian constitutions but also in the Azerbaijani one. The three South Caucasian republics were the only ones to retain the state language articles among all the Union republics. It seems that the renaming of place names intended to demonstrate the position of the local communist authorities towards the language issue by reinforcing the Armenian-ness of the republic. Therefore, the place-name replacements of 1978 in Armenia should be seen in the context of the changes in the Soviet constitution. The Chart 1 summarises the dynamics of place-names replacement.

Chart 1 - The dynamics of place-names replacement in Armenia

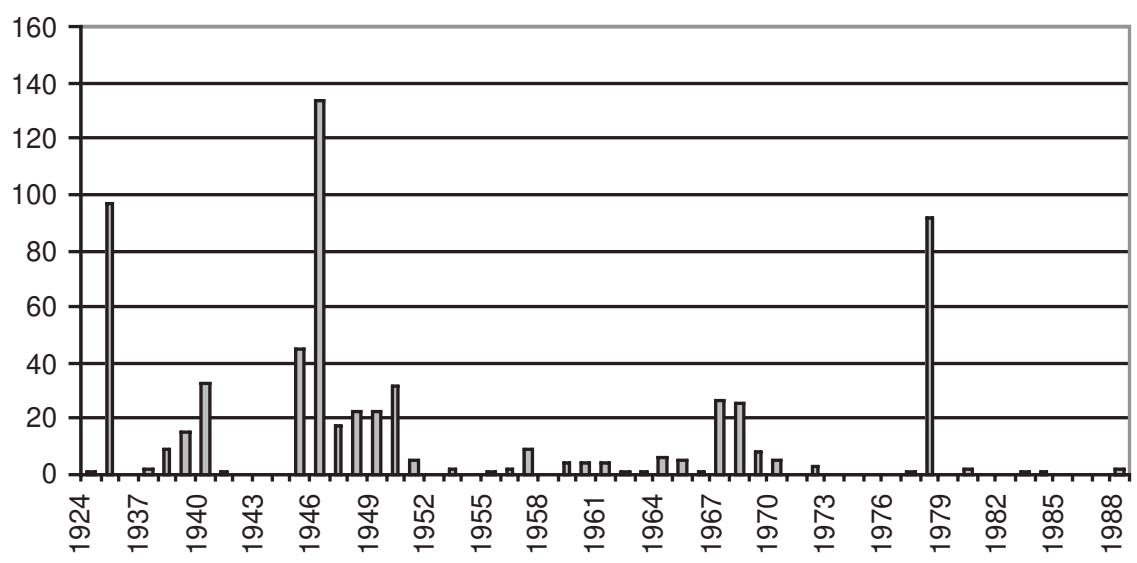

\section{The scale of renamings}

This analysis is based on the following sources: the earliest source on place-names is the large-scale map $(1: 200,000)$ of the Armenian SSR published in $1932^{39}$ which gives a very detailed picture of Armenian place-names at that time. Other important sources of data were the six issues of the official publication Administrativeterritorial division of the Armenian SSR. ${ }^{40}$ These volumes were published primarily for local administrators and apparently contained a complete list of populated places in Armenia. To assess the scale of renamings it is necessary to establish the number of populated places in the Armenian SSR. Surprisingly, it is rather difficult to give a definite figure for the total number of place-names, as this was not constant. There are evidently two reasons for these variations. Firstly, the

39. Kh. A. Avdalbekian, Karta Sotsialisticheskoi Sovetskoi Respubliki Armenii, 1:200,000 (Yerevan, 1932).

40. Haikakan SSH, varcha-teritorial bazhanume ar 1 hunvari 1948 t. (Armenian SSR, Administrative territorial structure on January 1, 1948), (Yerevan, 1948); ibid.: ...ar 1 hoktemberi 1955 t. (on October 1, 1955), (Yerevan, 1955); ibid.: ... ar 1 marti 1964 t. (on March 1, 1964), (Yerevan, 1964); ibid.: ...ar 1971 t. (on 1971), (Yerevan, 1976); ibid.: ...ar 1976 t. (on 1976), (Yerevan, 1976); ibid.: ... ar 1988 t. (on 1988), (Yerevan, 1988). 
number of place-names differed significantly because of boundary changes with neighbouring Soviet republics. ${ }^{41}$ Overall, the total territory of the Armenian SSR diminished by more than $1,000 \mathrm{sq}$. km during the entire Soviet period. Also, social and political processes within the USSR such as industrialisation, urbanisation, deportations and resettlements also led to a constant decline in the number of placenames. The Soviet population census of 1959 showed that there were 1,026 villages in the Armenian SSR. This figure included 65 villages with a population between 5 and 50 people. ${ }^{42}$ The Chart 2 summarises the changes in the numbers of placenames in Armenian SSR.

Chart 2 - Number of place-names in Armenian SSR

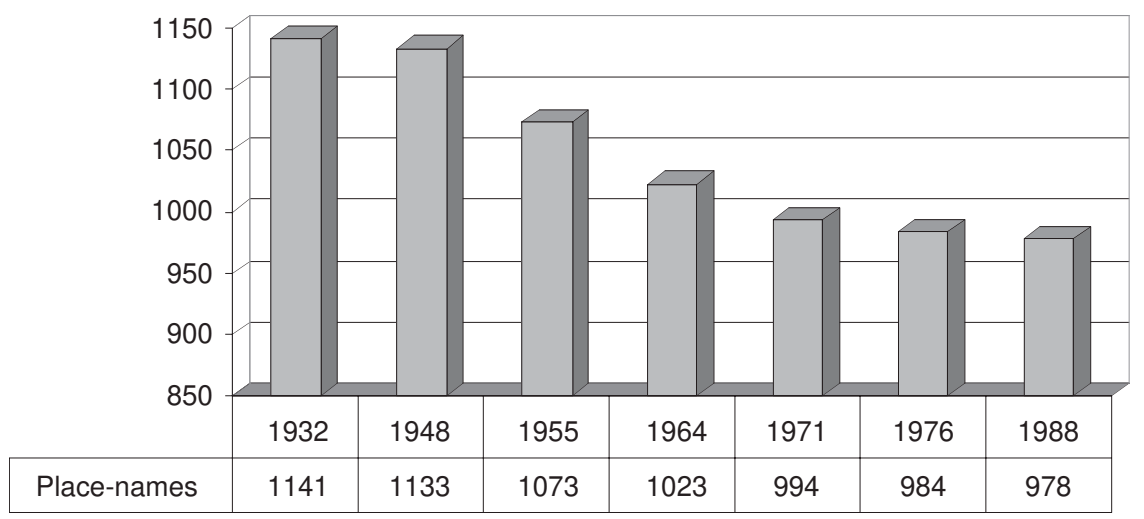

It is clear that during the 1932-1988 period, the number of place-names in Armenia fluctuated by $15 \%$. As the total number of place-names in Armenia declined, placename renamings became more frequent. The decline in the number of renamed place-names only occurred between 1955 (489 renamings) and 1964 (483 renamings). The impact of the renaming policy is evident. By 1988 some 60\% (598 out of 980) of place-names in the Armenian SSR had been renamed (see Chart 3). This figure exceeds the highest estimates of the Soviet place-name renamings which some authors place at around 50\%.

41. The territory of the SSRA (Armenian SSR) in 1927 was 30,948 sq. km., it shrank to 29,697 sq. $\mathrm{km}$. by 1932 and by the time of the dissolution of the USSR it had only 29,800 sq. km. (Atlas Soiuza Sovetskikh Sotsialisticheskikh Respublik, composed by A. F. Belavin, second, expanded edition (Moscow-Leningrad, 1928): 70; Kh. A. Avdalbekian, op. cit.; I. A. Gogoverishvili, O. A. Khachalag, eds, Armianskaia SSR [Map]. (Moscow: Glavnoe upravlenie geodezii i kartografii pri Sovete Ministrov SSSR, 1990).

42. Itogi vsesoiuznoi perepesi naseleniia 1959 goda. Armianskaia SSR (Moscow: Tsentral'noe statisticheskoe upravlenie pri Sovete Ministrov SSSR, 1963): 14-15. 


\section{Chart 3 - Proportion of renamings in Armenia}

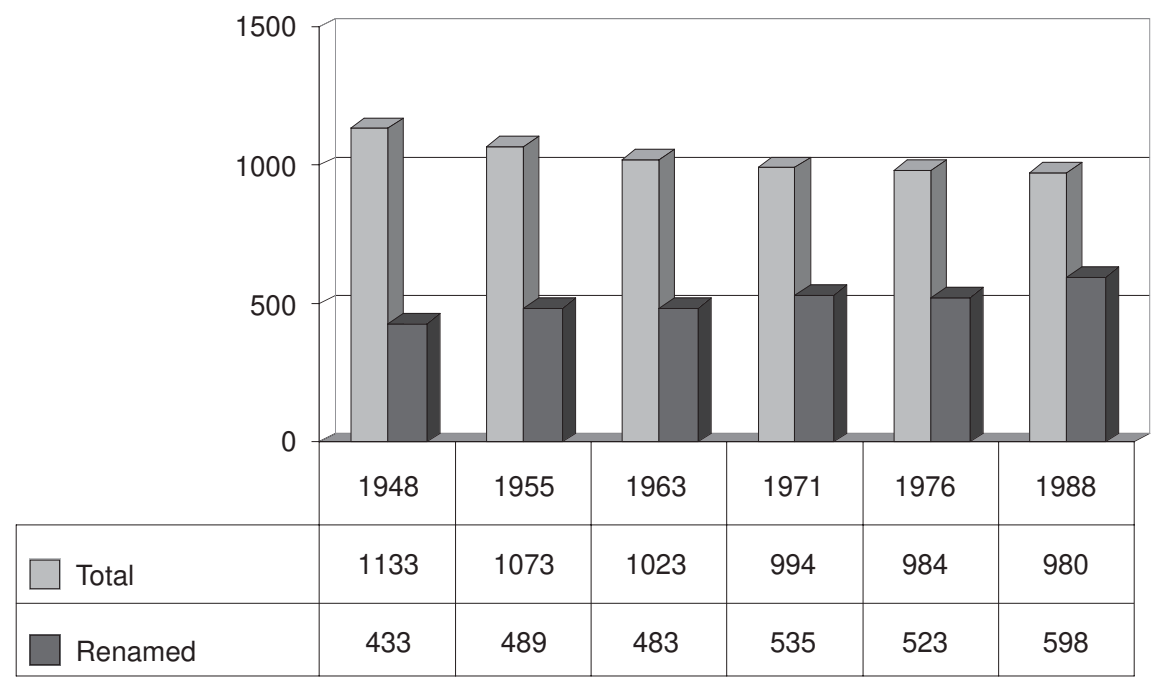

This unusually high figure reflects the total change of the cultural landscape of the Armenian SSR. If we also consider the spatial distribution of the renamed placenames up to 1988 (see Map 1), it is clear that the distribution of the renamings varied from $12 \%$ in some districts to nearly $100 \%$ in others. Place-name renamings were most numerous in the central valleys, whereas the fewest occurred in the mountainous and forested areas of the South and North-East of the country. The explanation for this is that the valleys of Armenia were badly affected by the Turkish-Persian wars of sixteenth-eighteenth centuries, with the loss of their cultural landscape, while the inaccessible areas of the North-East and South were relatively unaffected by those events.

To present as complete a picture of the renamings in Armenia as possible, I will also briefly address the question of physical-geographic toponyms. The main source for this analysis is a book Geographic names of the Armenian SSR, published in 1951. The publication contains names of "all mountain ranges, plateaus, most mountain passes, major mountains and peaks, large rivers and tributaries, and 1/4 of the lakes" 43 i.e. the list of names of physical features is not a full one. The new (i.e. renamed) and old place-names are listed in one list in alphabetical order, which makes it impossible to make any comparison between renamed and old toponyms. Therefore, I had to compose the list anew. The limited resources for this analysis do not allow one to determine whether there was any temporal or spatial pattern to the distribution of the renamings. It is therefore clear that this analysis has some limitations but it should suffice as a general illustration for the major trends. 


\section{Hydronyms}

There are 107 hydronyms in the list, 71 (66\%) of which were renamed. There were a number of hydronyms, each with a distinctly Turkic stem relating to water: -çay (river), -gól (lake), -bulağ (stream, spring), -su (water meaning river). There were 26 of these toponyms, most of which were changed for their Armenian equivalents. Thus -gel was changed for -lich (out of 12 stems -gól, 11 were changed into lich), -bulağ was substituted by akhbiur (out of 4 stems -bulağ, 2 were changed into -akhbiur and one into Russian -rodnik), the only Turkic stem -su was changed into its Armenian equivalent -djur. The situation with 9 Turkic stems -çay was different as only one was replaced by an Armenian equivalent - get while in the remaining 8 cases the stem was dropped completely in the new name. If one considers the method of renamings, it is possible to distinguish four categories. 1. Loan-translation or calque when the entire place-name is fully translated, for instance: Turkic Karagól into Armenian Sevlich (black+lake); Balihli into Dzyknaget (fish+river). 2. Semi-calque or hybrid renamings: Şorbulağ into Mushakhbiur, Karagól into Karilich (in these two pairs only the second part of a toponym is translated). 3. Linguistic adaptation: Kafan into Kapan (Hapan), Ertapin into Artabun. Finally, the fourth category is a complete substitution: Basut into Tsav; Çayzami into Kashuni. These four categories are distributed rather unequally as there were 5 cases of loan-translation or calque, 12 cases of semi-calque or hybrid, 27 cases of adaptation, and 29 cases of complete substitution. Thus, more than half of the renamed hydronyms have retained continuity with the old ones.

\section{Oronyms}

Out of 315 listed oronyms, 164 (52\%) were renamed. Following the pattern established for hydronyms we can apply the same four categories here as well. There were 8 instances of loan-translation or calque, for instance: $A k d a \breve{g}$ into Spitakasar (white+mountain); Damurli (Demirli) into Erkrasar (iron+mountain). There were 14 cases of semi-calque or hybrids: Murad-tapa (-tepe) into Muradsar, Kamarkaya into Kamarkar. Adaptation was the most widespread method of renaming, being used in 98 cases. For example: Hartinlar into Hartinler (Turkic plural ending -lar substituted here by Armenian word for mountain -ler), Išihli into Ishhansar. The second most common way of renamings was complete substitution (44 cases), such as: Maman into Tsahkadzor, Boğutlu into Ardeni. In the case of oronyms, the number of Turkic stems for mountains is insignificant: -da $\breve{g}$ (mountain) - 17 cases, -tapa (tepe) (hill) - 9 cases, -kaya (rock, cliff) - only 4 cases. These Turkic word-formants were changed in the following way: out of 17 words -da $\breve{g}, 10$ were translated into its Armenian equivalent -sar; 6 out of 9 -tapa were changed either into -sar or -blur, and all 4 -kaya were changed into-kar. As was the case with the hydronyms a large proportion of renamed oronyms maintain continuity with the old toponyms (120 out of 164 or $73 \%$ to be precise). 
This short overview of the renamings of natural features demonstrates that the general trend in the Armenian SSR was to replace Turkic toponyms with Armenian ones.

\section{The nature of renamings}

This paper addresses the role of place-names in the national identity, and it is the "national" aspect of place-names that we are interested in. One approach is to sort place-names according to their "national connotation." However, from the point of view of traditional onomastics this is difficult. Nearly every place-name contains elements from different linguistic layers and from different periods, so it is impossible to speak of the "national connotation" of a place-name. We deal firstly with an artificially created toponymic landscape. The origin of a place-name is well known, its etymology is completely clear, and the circumstances that led to and the timing of its emergence are known. Then it is the symbolic role and meaning of a place-name that are more important than its actual etymology. It is how a particular place-name is being perceived by a population rather than what it actually is that matters for the assessment of its role in the national identity. Therefore, we can speak of the "national connotation" of a place-name when it is necessary to understand its role in the national identity. Having said that, we can distinguish four major placename categories of the new place-names in Armenia. Armenian place-names; Turkic place-names, socialist place-names; and other place-names (see Chart 4).

\section{Chart 4 - The nature of renamed place-names in Armenia}

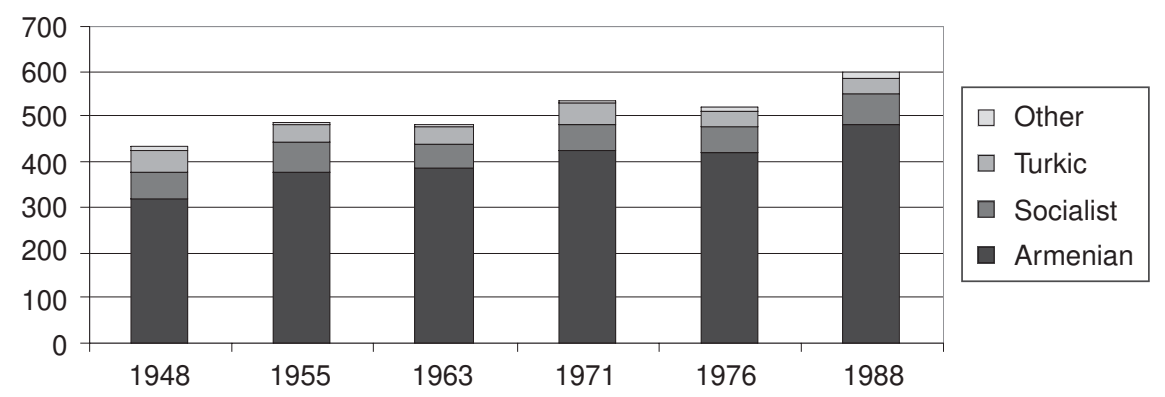

From this chart it can be seen that the majority of the renamed place-names were Armenian, followed by "socialist" place-names, "Turkic" place-names and finally an insignificant number of "other" place-names. If the categories of "Armenian" and "Turkic" place-names are self-explanatory, then the category of "socialist" placenames deserves more explanation. The famous Soviet ideological formula "national by form, socialist by content" was widely applied in place-naming policies within the Union republics. Several methods were used to implement the formula. One method was to use the names of the local communists. In Armenia there were Stepanavan and 
Shaumian (both places named after an ethnic Armenian Bolshevik, Stepan Shaumian), Mikoyan and Anastasavan (named after another Armenian Bolshevik Anastas Mikoyan). In Azerbaijan there were Azizbekov, Narimanabad, Hanlar (all named after local communists). In Georgia there were Tshakaya, Ordzhonikidze, Tsulukidze. Another group of Soviet toponyms originated from the standard figures of the Soviet pantheon "Lenin" and "Stalin." The base word was modified by adding the local place-formant - Leningrad (RSFSR), Leninakan (Armenian SSR), Leninabad (Tadjik SSR), Leninzholi (Kazakh SSR), Leningori (Georgian SSR), Stalingrad (RSFSR), Stalino (Ukrainian SSR), Staliniri (Georgian SSR). Yet another category of Soviet toponyms was derived from words that were important to the Communist regime, such as "October," "May," or neologisms "Soviety" and "Komsomol." Thus in the Armenian SSR there were Sovetashen, Mayisian, Hoktemberian and Noyenberian (the Sovietisation of Armenia occurred in November 1920) in Azerbaijan there were Oktiabriabad, Birmay (1 May), etc.

Hence, within the ideologically motivated Soviet place-names, it is possible to distinguish the national markers. In the case of Armenia there were three subcategories of socialist place-names - "Armenian-socialist," "Azerbaijani-socialist," and "neutral-socialist." Examples of "Armenian-socialist" have already been mentioned Shaumian and Mikoyan. Azizbekov was an "Azerbaijani-socialist" placename (named after Meshadi Azizbekov, an ethnic Azerbaijani and member of the Baku Commune). Another category of socialist place-names was "neutral-socialist." Unlike the first two categories of place-names which had clearly distinguishable ethnic markers, the "neutral-socialist" place-names were free of Armenian or Azerbaijani connotations. For instance: Fioletovo (after Ivan Fioletov an ethnic Russian member of the Baku Commune) or Kalinono (after Mikhail Kalinin the chairman of the Central Executive Committee of the USSR). The distribution of these sub-categories of "socialist" place-names in Armenia can be seen from Chart 5.

\section{Chart 5 - "Socialist" renamings in Armenia}

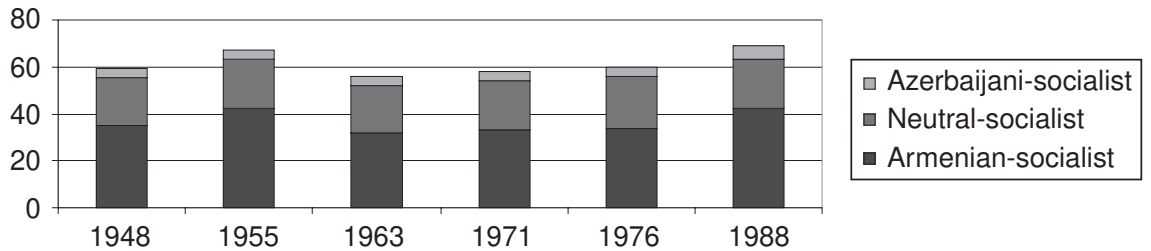

"Armenian-socialist" place-names once again made up the majority, followed by the "neutral socialist," and "Azerbaijani-socialist" place-names. The nature of the changing cultural landscape of Armenia can be seen by comparing the maps showing Turkic and Armenian place-names in 1932 (Map 2), with a later map from 1988 (Map 3). It is clear that the place-naming campaigns that took place in the Armenian SSR succeeded in largely replacing the Turkic place-name landscape with an Armenian one. 
One more aspect of renamings in Armenia also deserves mention. Renamings have always reflected the demographic circumstances on the ground. Thus, Armenian place-names only replaced Turkic place-names if the population of the place was Armenian. If the population was Azerbaijani, the new place-name would either be Turkic or Azerbaijani-socialist. The Zangibasar district was created on December 31, 1937 from parts of the Echmiadzin and Artashat districts. It was the smallest district in Armenia with an area of $160 \mathrm{sq}$. km. The majority of its 31 placenames as well as its population were Turkic. All of the 11 renamings that occurred in the district were mere replacements of one Turkic place-name by another. The district was abolished sometime between 1948 and 1955 (probably in 1949 as a result of the Soviet policies of Azerbaijani resettlement). After 1948, several renamings occurred there from Turkic into Armenian, which indicates the changes in ethnic composition of the district. In fact, the creation of this small district with its mainly Turkic population and the nature of renamings there during the decade 1937-1948 indicate that the Azerbaijanis received unofficial cultural autonomy. By late 1980's there were 152 Azerbaijani villages in the Armenian SSR all with Turkic place-names. The renamings of the Azerbaijani villages always retained the Turkic character - Karakoyün (Azizlu), Karaçanta (Azizbekov), Canahmed (Günasli), Itkran (Gülistan), Ilanli (Çaybasar).

Similarly, unacceptable to the Soviet regime Russian place-names were replaced by Armenian ones if there was little or no Russian population left, for instance Elenovka was renamed Sevan. However, when the Russian population was present the renaming would reflect the ethnic character of the place, for instance: Russkie Gergeri - were renamed Pushkino (after the Russian writer A. S. Pushkin); Voskresenovka (an unacceptable religious name meaning Resurrection) was renamed Lermontovo (after the Russian poet Lermontov); Vorontsovka (after the Caucasian Viceroy Count Vorontsov) was renamed Kalinino, and finally Nikitino (after the Tsarist officer) was renamed Fioletovo.

\section{Conclusion}

"The man-made landscape - [...] provides strong evidence of the kind of people we are, and were, and in the process of becoming. In other words, the culture of any nation is unintentionally reflected in its ordinary vernacular landscape; people will not change that landscape unless they are under very heavy pressure to do so. We must conclude that if there is really a major change in the look of the cultural landscape, then there is very likely a major change in one national culture at the same time" writes Pierce F. Lewis. ${ }^{44}$ The place-naming policy in Soviet Armenia demonstrates that even under the totalitarian communist regime a conscious policy 
directed at the creation of a national cultural landscape was possible. Several factors made it possible:

- The decline of the initially strong communist ideology in the USSR and the rise of nationalism in the Soviet society especially after WWII.

- The ideological trends of the USSR took place in Armenia as well. In the Armenian SSR they acquired a unique direction determined by the specific features of the Armenian national identity.

- The events of 1915 in the Ottoman Empire have created a strong anti-Turkish sentiment, which eventually influenced the policy of the Armenian communists.

- This policy was only possible under the following conditions: the Soviet authorities were always anxious about separatism and therefore the anti-Turkish direction of Armenian nationalism was perceived as less dangerous and was tolerated.

- In the course of the 70 years of communist rule, the Armenian communists contributed greatly to the formation of the Armenian national identity. The destruction of the Turkic cultural landscape and the re-creation of the Armenian one has been a symbolic way to overcome the traumatic experiences of 1915 .

International Relations Department

London School of Economics

Houghton Street

London WC2A $2 A E$

A.Saparov@1se.ac.uk 